\title{
Analisis Kuat Tekan Beton yang Menggunakan Pasir Laut sebagai Agregat Halus pada Beberapa Quarry di Kabupaten Fakfak
}

\author{
Imran $^{1, \mathrm{a}}$ dan Muhammad Yunus ${ }^{1, \mathrm{~b}}$ \\ ${ }^{1}$ Jurusan Teknik Sipil, Politeknik Negeri Fakfak, Jl. Imam Bonjol Atas, Air Merah, Wagom, Fakfak, 98612, Indonesia \\ aimran@polinef.id, \\ bmuhammad_unus@yahoo.com
}

Abstact - SNI 03-6861-1-2002, states that the fine aggregate used in concrete structures should use river sand. However, the use of fine aggregate in Fakfak regency in general is still dependent on sea sand potential is quite large. The purpose of this study were: 1) determine the characteristics of sea sand in Fakfak regency as a component of the concrete mix; 2) determine the strength of concrete resulting from the use of sea sand. This research is an experimental research laboratory by means of sample testing and analysis of the characteristics of aggregates and concrete compressive test using a compression test machine. Results of testing the characteristics of fine aggregate to quarry in Fakfak regency consisting of quarry Kampung Seberang, quarry Kampung Sungai, quarry Tanjung Wagom and coarse aggregate from the quarry Kayuni can generally be used for a mixture of concrete for eligible characteristics of concrete aggregate but fine aggregate (sand) it is best to Tanjung Wagom quarry because of the fineness modulus 2.93 and included in zone 2. Compressive strength characteristics resulting from the quarry Kampung Seberang $122.84 \mathrm{~kg} / \mathrm{cm}^{2}$ quarry Kampung Sungai $129.59 \mathrm{~kg} / \mathrm{cm}^{2}$ and quarry Kampung Tanjung Wagom 144.27 $\mathrm{kg} / \mathrm{cm}^{2}$ of the planned concrete quality $250 \mathrm{~kg} / \mathrm{cm}^{2}$ or down $50.86 \%$, quarry Kampung Sungai $48.16 \%$ and quarry Tanjung Wagom $42.29 \%$ down or strength is only reached at quarry Kampung Seberang $49.14 \%$, quarry Kampung Sungai $51.84 \%$ and quarry Tanjung Wagom down 57.71\%

Keywords - fine aggregate, Sea Sand, and Concrete Compressive Strength Abstrak - SNI 03-6861-1-2002, menyebutkan bahwa agregat
halus yang digunakan pada struktur beton sebaiknya
menggunakan pasir sungai. Namun demikian penggunaan
agregat halus di kabupaten Fakfak secara umum masih
tergantung pada pasir laut yang potensinya cukup besar. Tujuan
penelitian ini adalah : 1) mengetahui karakteristik pasir laut di
Kabupaten Fakfak sebagai penyusun campuran beton; 2)
mengetahui kuat tekan beton yang dihasilkan akibat penggunaan
pasir laut. Penelitian ini merupakan penelitian eksperimental
laboratorium dengan cara pengujian sampel dan analisis
karakteristik agregat dan uji tekan beton menggunakan
compression machine test. Hasil pengujian karakteristik agregat
halus untuk quarry di Kabupaten Fakfak yang terdiri atas quarry Kampung Seberang, quarry Kampung Sungai, quarry Tanjung Wagom dan agregat kasar dari quarry Kayuni secara umum dapat digunakan untuk bahan campuran beton karena memenuhi syarat karakteristik agregat beton tetapi agregat halus (pasir) yang paling baik adalah quarry Tanjung Wagom karena dengan modulus kehalusan 2.93 dan masuk dalam zone 2. Kuat tekan karakteristik yang dihasilkan dari quarry Kampung Seberang 122,84 kg/cm ${ }^{2}$ quarry Kampung Sungai $129,59 \mathrm{~kg} / \mathrm{cm}^{2}$ dan quarry Kampung Tanjung Wagom 144,27 kg/ $\mathrm{cm}^{2}$ dari mutu beton yang direncanakan $250 \mathrm{~kg} / \mathrm{cm}^{2}$ atau turun $50,86 \%$, quarry Kampung Sungai 48,16 \% dan quarry Tanjung Wagom turun $42,29 \%$ atau kekuatan hanya dicapai pada quarry kampung seberang 49,14\%, quarry Kampung Sungai 51,84\% dan quarry Tanjung Wagom turun 57,71\%

\section{Kata Kunci-Agregat Halus, Pasir Laut, dan Kuat Tekan Beton}

\section{Pendahuluan}

Perkembangan infrastruktur di Indonesia dari waktu ke waktu dirasakan perubahannya semakin cepat dan pesat. Seiring dengan perkembangan tersebut, konstruksi beton mendominasi pekerjaan infrastruktur seperti pembangunan gedung, jembatan, bendungan, drainase, dermaga, pondasi dan jalan raya. Pemilihan jenis konstruksi beton disebabkan karena kemudahan dalam pengerjaan (workability), mudah dibentuk, waktu untuk konstruksi, biaya pemeliharaan struktur rendah, dan sebagainya. Sedangkan dari segi kualitasnya suatu konstruksi beton harus memiliki kekakuan yang besar (rigid), kekuatan (strength), serta awet (durability). Namun demikian terdapat beberapa kekurangan dalam pekerjaan struktur beton antara lain kekuatan tarik yang lemah, memerlukan biaya untuk bekisting dan perancah, serta memiliki sifat yang tergantung waktu (susut dan rangkak) [1]. 
Secara umum diketahui bahwa komponen penyusun utama pada beton adalah agregat. Kandungan agregat dalam beton kira-kira mencapai $70 \%-75 \%$ dari volume beton. Agregat sangat berpengaruh terhadap sifat-sifat beton, sehingga pemilihan agregat merupakan suatu bagian penting dalam pembuatan beton. Agregat dibedakan menjadi dua macam yaitu agregat halus dan agregat kasar yang didapat secara alami atau buatan.

Pemakaian agregat alam merupakan komponen penyusun utama pada beton yang harus diperhatikan ketersediaannya. Tidak semua daerah memiliki potensi ketersediaan agregat alam yang sama. Salah satu daerah di Indonesia yang kurang memiliki potensi agregat halus normal (pasir sungai) yang lazim digunakan pada pekerjaan beton adalah di Kabupaten Fakfak Provinsi Papua Barat [2].

SNI 03-6861.1-2002 [3], menyebutkan bahwa agregat halus yang digunakan pada struktur beton sebaiknya menggunakan pasir sungai. Namun demikian, penggunaan agregat halus di kabupaten Fakfak secara umum masih tergantung pada pasir laut yang potensinya cukup besar di daerah ini. Hampir seluruh pekerjaan konstruksi menggunakan pasir laut sebagai agregat utama penyusun beton. karena potensi pasir laut yang ada di Kabupaten Fakfak cukup besar [2].

Pemanfaatan penggunaan pasir laut dalam pekerjaan konstruksi beton dari sisi ekonomi memang mempunyai keuntungan. Salah satunya adalah meningkatkan pendapatan masyarakat pengumpul pasir laut yang tersebar di seluruh daerah yang ada di Kabupaten Fakfak. Disamping itu potensi ketersediaan pasir laut cukup besar dan mampu mengakomodir semua jenis pekerjaan konstruksi beton yang ada di daerah ini. Perbedaan kuat tekan tekan beton yang menggunakan pasir laut sebagai agregat halus tergantung pada karakteristik agregatnya. Campuran beton yang menggunakan pasir laut dengan perlakuan khusus menghasilkan kuat tekan beton yang lebih tinggi dibanding dengan campuran beton tanpa perlakuan khusus [4].

Penelitian ini akan mengetahui karakteristik pasir laut di Kabupaten Fakfak sebagai agregat halus penyusun campuran beton dan kuat tekan beton yang dihasilkan atas penggunaan pasir tersebut.

\section{Metode Penelitian}

\section{A. Lokasi dan Waktu Penelitian}

Penelitian eksperimental ini dilakukan di Laboratorium Uji Bahan Program Studi Teknik Sipil Politeknik Negeri Fakfak Provinsi Papua Barat. Pelaksanaan Penelitian selama 6 (enam) bulan yang meliputi kegiatan persiapan material, pengujian agregat, mix design concrete, pembuatan benda uji, pengujian kuat tekan dan analisis data.

\section{B. Tahapan Penelitian}

Tahapan dalam pelakasanaan penelitian ini adalah:

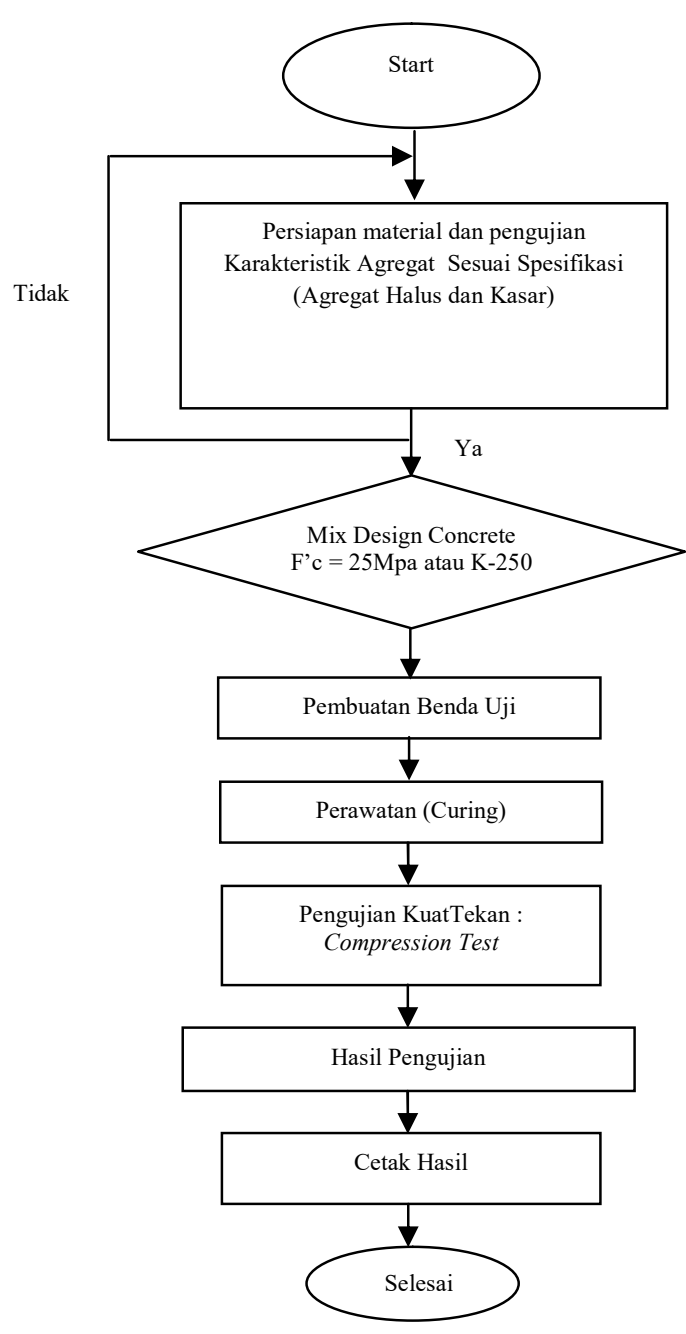

Gambar 1. Bagan Alir Tahapan Penelitian 


\section{Rancangan Sampel Penelitian}

Pembuatan sampel benda uji dalam penelitian ini menggunakan silinder ukuran $15 \times 30 \mathrm{~cm}$. Adapun jumlah sampel yang digunakan dalam penelitian ini:

Tabel 1 Sampel penelitian

\begin{tabular}{|c|c|c|c|c|}
\hline No. & $\begin{array}{c}\text { Sampel } \\
\text { Benda Uji } \\
\text { (Pasir } \\
\text { Quarry A) }\end{array}$ & $\begin{array}{c}\text { Sampel } \\
\text { Benda Uji } \\
\text { (Pasir } \\
\text { Quarry B) }\end{array}$ & $\begin{array}{c}\text { Sampel } \\
\text { Benda Uji } \\
\text { (Pasir } \\
\text { Quarry C) }\end{array}$ & $\begin{array}{c}\text { Pengujian } \\
\text { (hari) }\end{array}$ \\
\hline 1 & 3 Sampel & 3 Sampel & 3 Sampel & 3 \\
\hline 2 & 3 Sampel & 3 Sampel & 3 Sampel & 7 \\
\hline 3 & 3 Sampel & 3 Sampel & 3 Sampel & 28 \\
\hline$\Sigma$ & 9 Sampel & 9 Sampel & 9 Sampel & - \\
\hline \multicolumn{5}{|c|}{ Total 27 Sampel } \\
\hline
\end{tabular}

\section{Pengujian Karakteristik Agregat}

Tabel 2 Metode pengujian agregat

\begin{tabular}{|c|c|c|}
\hline No. & Jenis Pengujian & Metode \\
\hline 1. & AnalisaSaringan & SNI 03-1968-1990 \\
\hline 2. & $\begin{array}{c}\text { Berat Jenis dan Penyerapan } \\
\text { Agregat Halus }\end{array}$ & SNI 03-1970-1990 \\
\hline 3. & $\begin{array}{c}\text { Berat Jenis dan Penyerapan } \\
\text { Agregat Kasar }\end{array}$ & SNI 03-1969-1990 \\
\hline 4. & Kadar Air & SNI 03-1971-1990 \\
\hline 5. & Berat Volume & SNI 03-4804-1998 \\
\hline
\end{tabular}

Sumber : Attamimi, 2015[5]

\section{E. Pengujian Kuat Tekan}

Hasil uji kuat tekan beton menggunakan compression machine test dianalisis menggunakan persamaan kuat tekan (SK SNI 03-1974-1990) [6]:

$$
f C=\frac{P}{A}
$$

Dimana:

$$
\begin{aligned}
& \mathrm{fc}=\text { Kuat tekan }\left(\mathrm{kg} / \mathrm{cm}^{2}\right) \\
& \mathrm{P}=\text { Beban yang dipikul }(\mathrm{kg}) \\
& \mathrm{A}=\text { Luas penampang yang dibebani }\left(\mathrm{cm}^{2}\right)
\end{aligned}
$$

\section{Hasil dan Pembahasan}

Hasil pengujian karakteristik agregat halus (pasir) yang diambil dari tiga quarry berbeda di Kabupaten Fakfak dapat dilihat pada Tabel 3, Tabel 4, dan Tabel 5. Sedangkan untuk hasil pengujian karakteristik agregat kasar (batu pecah) yang diambil dari quarry Crusher Plant Kayuni dapat dilihat pada Tabel 6.

Tabel 3. Hasil pengujian karakteristik agregat halus (pasir) sampel berasal dari quarry Kampung Seberang

\begin{tabular}{|c|c|c|c|c|}
\hline No. & $\begin{array}{c}\text { Karakteristik } \\
\text { Agregat }\end{array}$ & Interval & $\begin{array}{c}\text { Hasil } \\
\text { Pengujian }\end{array}$ & Keterangan \\
\hline 1. & Kadar lumpur & $\begin{array}{l}\text { Maks. } \\
5 \%\end{array}$ & $2.77 \%$ & Memenuhi \\
\hline 2. & Kadar air & $0.5-5 \%$ & $3.78 \%$ & Memenuhi \\
\hline 3. & Berat volume & $\begin{array}{l}1.4-1.9 \\
\mathrm{~kg} / \text { liter }\end{array}$ & 1.91 & Memenuhi \\
\hline 4. & Absorpsi & $0.2-2 \%$ & 0.75 & Memenuhi \\
\hline \multirow[t]{4}{*}{5.} & $\begin{array}{l}\text { Berat jenis } \\
\text { spesifik }\end{array}$ & & & \\
\hline & Bj. nyata & $1.6-3.3$ & 2.528 & Memenuhi \\
\hline & Bj. dasar kering & 1.6 & 2.481 & Memenuhi \\
\hline & $\begin{array}{l}\text { Bj. kering } \\
\text { permukaan }\end{array}$ & 1.6 & 2.500 & Memenuhi \\
\hline 6. & $\begin{array}{l}\text { Modulus } \\
\text { kehalusan }\end{array}$ & $\begin{array}{c}1.50- \\
3.80\end{array}$ & 2.170 & $\begin{array}{c}\text { Memenuhi } \\
\text { Zone } 3\end{array}$ \\
\hline
\end{tabular}

\begin{tabular}{|c|c|c|c|c|}
\hline No & $\begin{array}{c}\text { Karakteristik } \\
\text { Agregat }\end{array}$ & Interval & $\begin{array}{c}\text { Hasil } \\
\text { Pengujian }\end{array}$ & Keterangan \\
\hline 1. & Kadar lumpur & $\begin{array}{c}\text { Maks. } \\
5 \%\end{array}$ & $2.36 \%$ & Memenuhi \\
\hline 2. & Kadar air & $0.5-5 \%$ & $4.14 \%$ & Memenuhi \\
\hline 3. & Berat volume & $\begin{array}{c}1.4-1.9 \\
\mathrm{~kg} / \text { liter }\end{array}$ & 1.43 & Memenuhi \\
\hline 4. & Absorpsi & $0.2-2 \%$ & 1.84 & Memenuhi \\
\hline 5. & $\begin{array}{c}\text { Berat jenis } \\
\text { spesifik }\end{array}$ & & & \\
\hline & Bj. nyata & $1.6-3.3$ & 2.571 & Memenuhi \\
\hline & Bj. dasar kering & 1.6 & 2.455 & Memenuhi \\
\hline & $\begin{array}{c}\text { Bj. kering } \\
\text { permukaan }\end{array}$ & 1.6 & 2.500 & Memenuhi \\
\hline 6. & $\begin{array}{c}\text { Modulus } \\
\text { kehalusan }\end{array}$ & $\begin{array}{c}1.50- \\
3.80\end{array}$ & 1.836 & Memenuhi \\
\hline
\end{tabular}

Tabel 4. Hasil pengujian karakteristik agregat halus (pasir) sampel berasal dari quarry Kampung Sungai

\begin{tabular}{|c|c|c|c|c|}
\hline No & $\begin{array}{c}\text { Karakteristik } \\
\text { Agregat }\end{array}$ & Interval & $\begin{array}{c}\text { Hasil } \\
\text { Pengujian }\end{array}$ & Keterangan \\
\hline 1. & Kadar lumpur & $\begin{array}{l}\text { Maks. } \\
5 \%\end{array}$ & $4.21 \%$ & Memenuhi \\
\hline 2. & Kadar air & $0.5-5 \%$ & $4.00 \%$ & Memenuhi \\
\hline 3. & Berat volume & $\begin{array}{l}1.4-1.9 \\
\mathrm{~kg} / \text { liter }\end{array}$ & 1.52 & Memenuhi \\
\hline 4. & Absorpsi & $0.2-2 \%$ & $1.37 \%$ & Memenuhi \\
\hline \multirow[t]{4}{*}{5.} & $\begin{array}{l}\text { Berat jenis } \\
\text { spesifik }\end{array}$ & & & \\
\hline & Bj. nyata & $1.6-3.3$ & 2.847 & Memenuhi \\
\hline & Bj. dasar kering & 1.6 & 2.740 & Memenuhi \\
\hline & $\begin{array}{l}\text { Bj. kering } \\
\text { permukaan }\end{array}$ & 1.6 & 2.778 & Memenuhi \\
\hline 6. & $\begin{array}{l}\text { Modulus } \\
\text { kehalusan }\end{array}$ & $\begin{array}{c}1.50- \\
3.80\end{array}$ & 2.930 & $\begin{array}{l}\text { Memenuhi } \\
\text { Zone } 2\end{array}$ \\
\hline
\end{tabular}

Tabel 5. Hasil pengujian karakteristik agregat halus (pasir) sampel berasal dari Quarry Tanjung Wagom 
Tabel 6. Hasil pengujian karakteristik agregat kasar (batu pecah) sampel berasal dari quarry Crusher Plant Kayuni

\begin{tabular}{|c|c|c|c|c|}
\hline No. & $\begin{array}{c}\text { Karakteristik } \\
\text { Agregat }\end{array}$ & Interval & $\begin{array}{c}\text { Hasil } \\
\text { Pengujian }\end{array}$ & Keterangan \\
\hline 1. & Kadar lumpur & $\begin{array}{c}\text { Maks. } \\
1 \%\end{array}$ & $2.54 \%$ & $\begin{array}{c}\text { Tidak } \\
\text { Memenuhi }\end{array}$ \\
\hline 2. & Kadar air & $0.5-2 \%$ & $2.78 \%$ & $\begin{array}{c}\text { Tidak } \\
\text { Memenuhi }\end{array}$ \\
\hline 3. & Berat volume & $\begin{array}{l}1.4-1.9 \\
\mathrm{~kg} / \text { liter }\end{array}$ & 1.600 & Memenuhi \\
\hline 4. & Absorpsi & $0.2-2 \%$ & $2.13 \%$ & Memenuhi \\
\hline \multirow[t]{3}{*}{5.} & $\begin{array}{l}\text { Berat jenis } \\
\text { spesifik }\end{array}$ & & & \\
\hline & Bj. dasar kering & 1.6 & 2.682 & Memenuhi \\
\hline & $\begin{array}{l}\text { Bj. kering } \\
\text { permukaan }\end{array}$ & 1.6 & 2.778 & Memenuhi \\
\hline 6. & $\begin{array}{l}\text { Modulus } \\
\text { kekasaran }\end{array}$ & $5.5-8.5$ & 6.653 & Memenuhi \\
\hline
\end{tabular}

Untuk mengetahui kekuatan mutu beton yang akan dihasilkan dengan menggunakan agregat halus (pasir) dan agregat kasar (batu pecah) digunakan mutu beton K250. Untuk quarry Kampung Seberang setelah dilakukan perhitungan penggabungan agregat diperoleh $40 \%$ pasir dan $60 \%$ batu pecah seperti ditunjukkan pada Tabel 7 .

Tabel 7. Hasil rancangan campuran beton sampel berasal dari quarry Kampung Seberang

\begin{tabular}{|c|c|c|c|c|}
\hline $\begin{array}{c}\text { Bahan } \\
\text { Beton }\end{array}$ & $\begin{array}{c}\text { Berat } \\
\left(\mathbf{K g} / \mathbf{m}^{\mathbf{3}}\right)\end{array}$ & $\begin{array}{c}\text { Rasio } \\
\text { Terhadap } \\
\text { Jumlah } \\
\text { Semen } \\
(\mathbf{K g})\end{array}$ & $\begin{array}{c}\text { Berat } \\
\text { untuk 1 } \\
\text { sampel } \\
(\mathbf{K g})\end{array}$ & $\begin{array}{c}\text { Berat } \\
\text { untuk 1 } \\
\text { sampel } \\
(\mathbf{K g})\end{array}$ \\
\hline Air & 182.8883 & 0.5085 & 0.9696 & 8.7261 \\
\hline Semen & 359.6491 & 1.0000 & 1.9067 & 17.1599 \\
\hline Pasir & 556.9555 & 1.5486 & 2.9527 & 26.5740 \\
\hline $\begin{array}{c}\text { Batu } \\
\text { Pecah }\end{array}$ & 1277.5070 & 3.5521 & 6.7726 & 60.9536 \\
\hline Jumlah & $\mathbf{2 . 3 7 7 , 0 0 0}$ & & $\mathbf{1 2 . 6 0 2 0}$ & $\mathbf{1 1 3 . 4 1 4 0}$ \\
\hline
\end{tabular}

Untuk quarry Kampung Sungai setelah dilakukan perhitungan penggabungan agregat diperoleh $30 \%$ pasir dan $70 \%$ batu pecah seperti ditunjukkan pada Tabel 8 . Sedangkan quarry Tanjung Wagom setelah dilakukan perhitungan penggabungan agregat diperoleh $40 \%$ pasir dan $60 \%$ batu pecah seperti ditunjukkan pada Tabel 9 .

Tabel 8. Hasil rancangan campuran beton sampel berasal dari quarry Kampung Sungai

\begin{tabular}{|c|c|c|c|c|}
\hline Bahan Beton & $\begin{array}{c}\text { Berat } \\
\left(\mathbf{K g} / \mathbf{m}^{\mathbf{3}}\right)\end{array}$ & $\begin{array}{c}\text { Rasio } \\
\text { Terhadap } \\
\text { Jumlah } \\
\text { Semen }(\mathbf{K g})\end{array}$ & $\begin{array}{c}\text { Berat untuk } \\
\mathbf{1} \text { sampel } \\
\mathbf{( K g )}\end{array}$ & $\begin{array}{c}\text { Berat untuk } \\
\mathbf{1} \text { sampel } \\
\mathbf{( K g )}\end{array}$ \\
\hline Air & 182.8883 & 0.5085 & 0.9696 & 8.7261 \\
\hline Semen & 359.6491 & 1.0000 & 1.9067 & 17.1599 \\
\hline Pasir & 556.9555 & 1.5486 & 2.9527 & 26.5740 \\
\hline Batu Pecah & 1277.5070 & 3.5521 & 6.7726 & 60.9536 \\
\hline Jumlah & $\mathbf{2 . 3 7 7 , 0 0 0}$ & & $\mathbf{1 2 . 6 0 2 0}$ & $\mathbf{1 1 3 . 4 1 4 0}$ \\
\hline
\end{tabular}

Tabel 9. Hasil rancangan campuran beton sampel berasal dari quarry Tanjung Wagom

\begin{tabular}{|c|c|c|c|c|}
\hline Bahan Beton & $\begin{array}{c}\text { Berat } \\
\left(\mathbf{K g} / \mathbf{m}^{3}\right)\end{array}$ & $\begin{array}{c}\text { Rasio } \\
\text { Terhadap } \\
\text { Jumlah } \\
\text { Semen }(\mathbf{K g})\end{array}$ & $\begin{array}{c}\text { Berat untuk } \\
\mathbf{1 ~ s a m p e l} \\
\mathbf{( K g )}\end{array}$ & $\begin{array}{c}\text { Berat untuk } \\
\mathbf{1 ~ s a m p e l} \\
(\mathbf{K g})\end{array}$ \\
\hline Air & 176.7036 & 0.4913 & 0.9368 & 8.4310 \\
\hline Semen & 359.6491 & 1.0000 & 1.9067 & 17.1599 \\
\hline Pasir & 764.6400 & 2.1261 & 4.0537 & 36.4832 \\
\hline Batu Pecah & 1124.0072 & 3.1253 & 5.9598 & 53.6297 \\
\hline Jumlah & $\mathbf{2 . 4 2 5 , 0 0 0}$ & & $\mathbf{1 2 . 8 5 6 0}$ & $\mathbf{1 1 5 . 7 0 4 0}$ \\
\hline
\end{tabular}

Setelah dilakukan perhitungan jumlah bahan selanjutnya dilakukan pencampuran bahan dan setelah itu didapatkan berat volume beton segar (basah). Untuk sampel quarry yang berasal dari Kampung Seberang, quarry Kampung Sungai, dan quarry Tanjung Wagom dapat dilihat pada Tabel 10.

Tabel 10. Berat beton segar yang dihasilkan

\begin{tabular}{|c|c|c|c|c|}
\hline $\begin{array}{c}\text { No. } \\
\text { Sampel }\end{array}$ & $\begin{array}{c}\text { Umur } \\
\text { (Hari) }\end{array}$ & $\begin{array}{c}\text { Berat } \\
\text { Sampel } \\
\text { (Quarry } \\
\text { Kampung } \\
\text { Seberang) } \\
\text { kg }\end{array}$ & $\begin{array}{c}\text { Berat } \\
\text { Sampel } \\
\text { (Quarry } \\
\text { Kampung } \\
\text { Sungai) } \\
\text { kg }\end{array}$ & $\begin{array}{c}\text { Berat } \\
\text { Sampel } \\
\text { (Quarry } \\
\text { Tanjung } \\
\text { Wagom) } \\
\text { kg }\end{array}$ \\
\hline 1 & 3 & 11.92 & 11,80 & 11,74 \\
\hline 2 & 3 & 11.78 & 11,68 & 11,64 \\
\hline 3 & 3 & 11.84 & 11,80 & 11,76 \\
\hline 4 & 3 & 11.70 & 11,84 & 11,60 \\
\hline 5 & 3 & 11.88 & 11,70 & 11,56 \\
\hline 6 & 3 & 11.88 & 11,88 & 11,74 \\
\hline 7 & 3 & 11.68 & 11,68 & 11,52 \\
\hline 8 & 3 & 11,96 & 11,96 & 11,77 \\
\hline 9 & 3 & 11,98 & 11,88 & 11,96 \\
\hline \multicolumn{2}{|c|}{ Jumlah } & $\mathbf{1 0 6 , 6 2}$ & $\mathbf{1 0 6 , 2 2}$ & $\mathbf{1 0 5 , 2 9}$ \\
\hline $\begin{array}{c}\text { Berat beton segar } \\
\text { rata-rata }\end{array}$ & $\mathbf{1 1 , 8 5}$ & $\mathbf{1 1 , 8 0}$ & $\mathbf{1 1 , 7 0}$ \\
\hline \multicolumn{2}{|c|}{$\begin{array}{c}\text { Volume } \\
\text { benda uji }\end{array}$} & $\mathbf{0 , 0 0 5 3 0}$ & $\mathbf{0 , 0 0 5 3 0}$ & $\mathbf{0 , 0 0 5 3 0}$ \\
\hline $\begin{array}{c}\text { Berat volume } \\
\text { beton segar }\end{array}$ & $\mathbf{2 2 3 5 , 8 5}$ & $\mathbf{2 2 2 7 , 3 6}$ & $\mathbf{2 2 0 7 , 8 6}$ \\
\hline
\end{tabular}

Berdasarkan hasil pengujian kuat tekan pada hari ke 28 (menggunakan faktor koreksi) dengan sampel berasal dari quarry Kampung Seberang diperoleh kuat tekan rata-rata sebesar 146,58 $\mathrm{kg} / \mathrm{cm}^{2}$, sampel yag berasal dari quarry Kampung Sungai diperoleh kuat tekan rata-rata $165,51 \mathrm{~kg} / \mathrm{cm}^{2}$ dan sampel yag berasal dari quarry Tanjung Wagom diperoleh kuat tekan rata-rata 200,00 $\mathrm{kg} / \mathrm{cm}^{2}$, seperti yang disajikan pada tabel 11 , tabel 12 dan tabel 13. 
Tabel 11. Kuat tekan beton dengan sampel berasal dari quarry Kampung Seberang

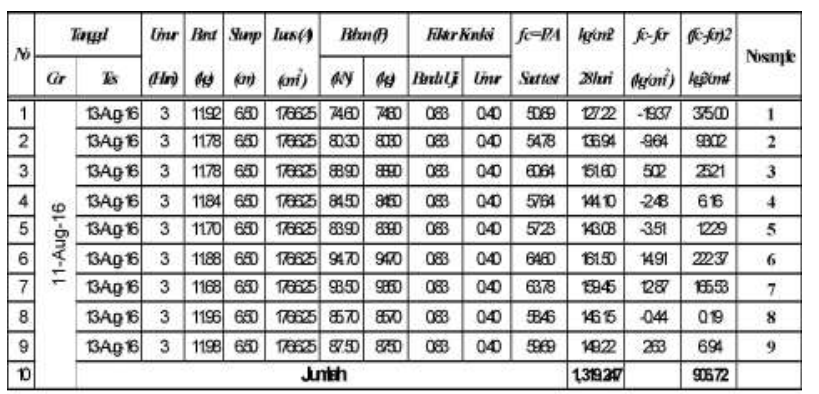

$$
f_{c r}=\frac{f_{c}}{n}=146,58 \mathrm{~kg} / \mathrm{cm}^{2}
$$

Tabel 12. Kuat tekan beton dengan sampel berasal dari quarry Kampung Sungai

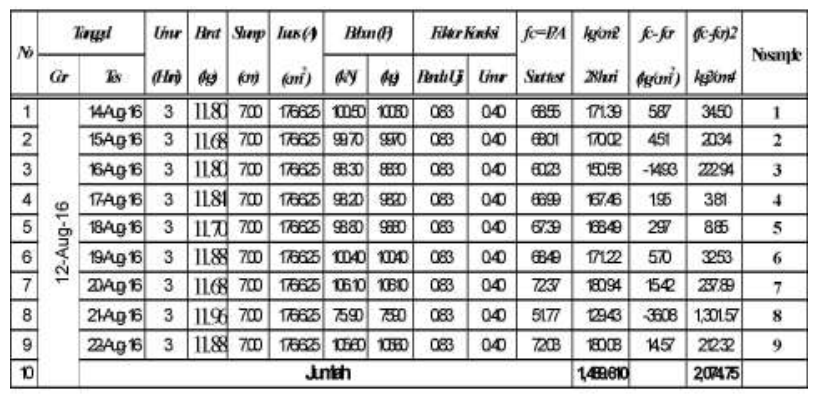

$$
f_{c r}=\frac{f c}{n}=165,51 \mathrm{~kg} / \mathrm{cm}^{2}
$$

Tabel 13. Kuat tekan beton dengan sampel berasal dari quarry Tanjung Wagom

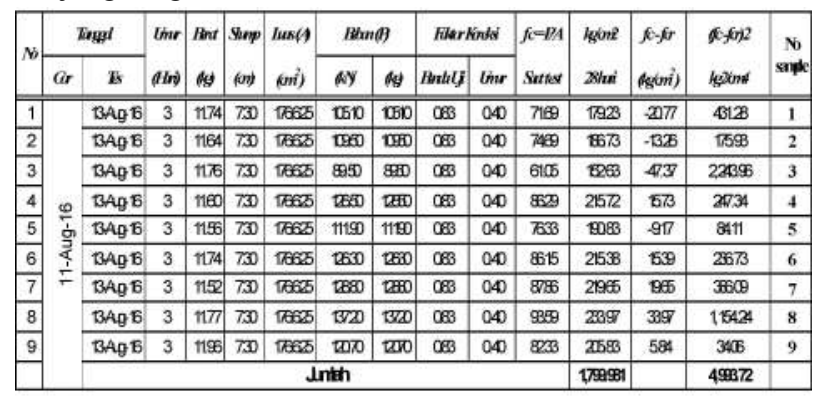

$$
\boldsymbol{f}_{\text {cr }}=\frac{f c}{n}=200,00 \mathrm{~kg} / \mathrm{cm}^{2}
$$

Pada pengujian agregat halus yang diperoleh dari ketiga quarry semua memenuhi syarat ketentuan untuk digunakan pada campuran beton. Namun ada perbedaan pada gradasi agregat halus (pasir) pada quarry Kampung Seberang masuk pada zone 4 yang berarti pasir sangat halus, sedangkan quarry Kampung Sungai masuk pada zone 3 kategori halus, pada quarry Tanjung Wagom masuk pada zone 2 masuk kategori agak kasar. Grafik hasil pengujian gradasi butiran agregat halus untuk quarry Kampung Seberang dapat dilihat pada Gambar 2, untuk quarry Kampung Sungai pada Gambar 3, sedangkan untuk quarry Tanjung Wagom pada Gambar 4.

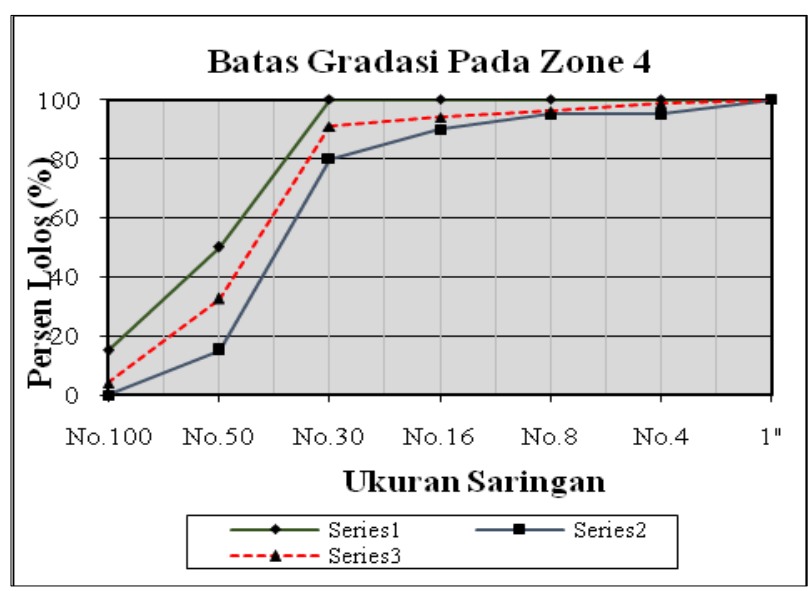

Gambar 2. Grafik Gradasi agregat halus (pasir) pada quarry Kampung Seberang

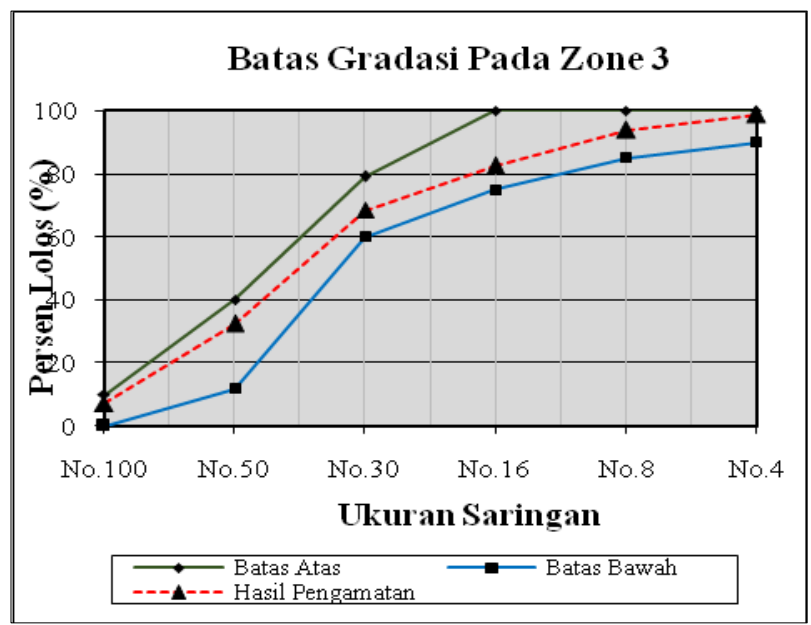

Gambar 3. Grafik Gradasi agregat halus (pasir) pada quarry Kampung Sungai

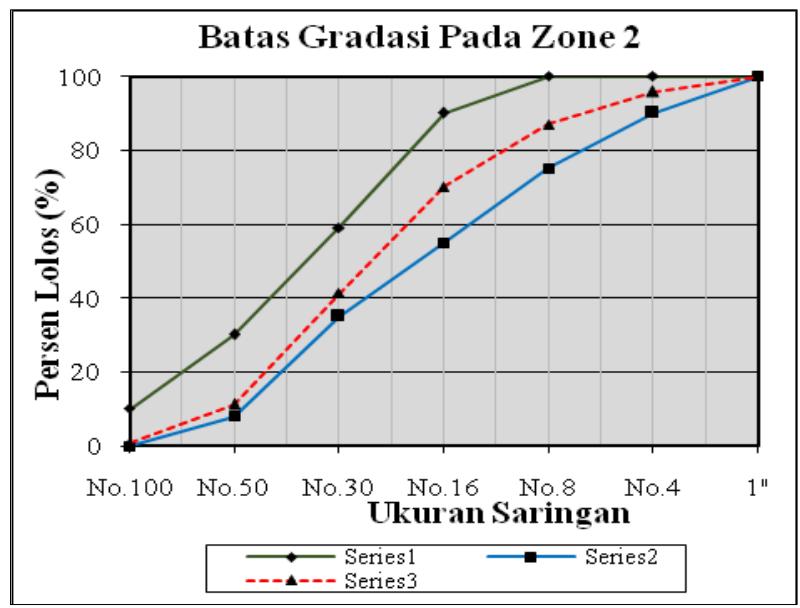

Gambar 4. Grafik Gradasi agregat halus (pasir) pada quarry Tanjung Wagom 
Berat volume beton segar yang dihasilkan setelah pencampuran ternyata tidak sesuai dengan mix design beton, dimana berat volume beton yang diperoleh dari hasil pencampuran lebih ringan. Hasil dari pengujian beton segar dapat dilihat pada Tabel 14 .

Tabel 14 . Tabel berat beton segar masing-masing quarry

\begin{tabular}{|c|c|c|c|c|}
\hline Nama Quarry & $\begin{array}{c}\text { Berat } \\
\text { Beton } \\
\text { Renc. } \\
\left(\mathbf{k g} / \mathbf{m}^{\mathbf{3}}\right)\end{array}$ & $\begin{array}{c}\text { Berat Beton } \\
\text { Hasil } \\
\text { Pencampur } \\
\mathbf{a n} \\
\left(\mathbf{k g} / \mathbf{m}^{\mathbf{3}}\right)\end{array}$ & $\begin{array}{c}\text { Berat } \\
\text { Selisih } \\
\left(\mathbf{k g} / \mathbf{m}^{\mathbf{3}}\right)\end{array}$ & Selisih \\
\hline Kampung Seberang & 2377 & 2235 & 142 & $14.2 \%$ \\
\hline Kampung Sungai & 2377 & 2227 & 150 & $15.0 \%$ \\
\hline Tanjung Wagom & 2425 & 2207 & 218 & $21.8 \%$ \\
\hline
\end{tabular}

Untuk quarry Kampung Seberang, diperoleh berat volume beton setelah pencampuran sebesar $2235 \mathrm{~kg} / \mathrm{m} 3$ dengan berat selisih sebesar $142 \mathrm{~kg} / \mathrm{m} 3$ dan persentase berat selisih $14.2 \%$, hal ini disebabkan karakteristik agregat halus di quarry Kampung Seberang didominasi pasir sangat halus walaupun dari hasil pengujian karakteristik agregat halus semua parameter nilai telah memenuhi sesuai yang disyaratkan. Untuk quarry Kampung Sungai, diperoleh berat volume beton setelah pencampuran sebesar $2227 \mathrm{~kg} / \mathrm{m} 3$ dengan berat selisih sebesar $150 \mathrm{~kg} / \mathrm{m} 3$ dan persentase berat selisih $15.0 \%$, hal ini disebabkan karakteristik agregat halus di quarry Kampung Seberang didominasi pasir halus walaupun dari hasil pengujian karakteristik agregat halus semua parameter nilai telah memenuhi sesuai yang disyaratkan. Untuk quarry Tanjung Wagom, diperoleh berat volume beton setelah pencampuran sebesar $2207 \mathrm{~kg} / \mathrm{m} 3$ dengan berat selisih sebesar $218 \mathrm{~kg} / \mathrm{m} 3$ dan persentase berat selisih $21.8 \%$, hal ini disebabkan karakteristik agregat halus di quarry Kampung Seberang didominasi pasir agak kasar walaupun dari hasil pengujian karakteristik agregat halus semua parameter nilai telah memenuhi sesuai yang disyaratkan. Rekapitulasi hasil pengujian kuat tekan beton untuk masing-masing quarry Kampung Seberang, quarry Kampung Sungai dan Tanjung Wagom ditunjukka pada Tabel 15.

Tabel 15. Rekapitulasi hasil pengujian kuat tekan

\begin{tabular}{|c|c|c|c|}
\hline Nama Quarry & $\begin{array}{c}\text { Kuat Tekan } \\
\text { Beton } \\
\text { Rata-Rata } \\
\left(\mathbf{k g} / \mathbf{c m}^{2}\right)\end{array}$ & $\begin{array}{c}\text { Kuat Tekan } \\
\text { Beton } \\
\text { Karakteristi } \\
\mathbf{k} \\
\left(\mathbf{k g} / \mathbf{m}^{\mathbf{3}}\right)\end{array}$ & $\begin{array}{c}\text { Modulus } \\
\text { Kohalusan } \\
\text { Agregat } \\
\text { Halus }\end{array}$ \\
\hline Kampung Seberang & 146.58 & 122.84 & 1.836 \\
\hline Kampung Sungai & 165.51 & 129.59 & 2.170 \\
\hline Tanjung Wagom & 200.00 & 144.27 & 2.930 \\
\hline
\end{tabular}

Hasil pengujian kuat tekan beton untuk quarry Kampung Seberang diperoleh kuat tekan rata-rata $146.58 \mathrm{~kg} / \mathrm{cm} 2$ dengan kuat tekan karakteristik sebesar $122.84 \mathrm{~kg} / \mathrm{cm} 2$, untuk quarry Kampung Sungai diperoleh kuat tekan beton rata-rata $165.51 \mathrm{~kg} / \mathrm{cm} 2$ dan kuat tekan karakteristik $129.59 \mathrm{~kg} / \mathrm{cm} 2$ sedangkan untuk quarry Tanjung Wagom diperoleh kuat tekan beton rata-rata $200.00 \mathrm{~kg} / \mathrm{cm} 2$ dan kuat tekan beton karakteristik 144.27 $\mathrm{kg} / \mathrm{cm} 2$.

Hal ini menunjukkan bahwa quarry yang memiliki nilai karakteristik modulus kehalusan agregat halus yang paling tinggi cenderung memiliki nilai kuat tekan beton yang tinggi seperti ditunjukkan pada Tabel 20. Pada Tabel 20 dapat dilihat quarry Tanjung Wagom memiliki nilai kuat tekan beton rata-rata yang paling tinggi sebesar $200.00 \mathrm{~kg} / \mathrm{cm} 2$ dan kuat tekan beton karakteristik $144.27 \mathrm{~kg} / \mathrm{cm} 2$ dengan nilai modulus kehalusan agregat halu sebesar 2.930. Quarry Kampung Sungai memiliki nilai kuat tekan beton rata-rata 165.51 $\mathrm{kg} / \mathrm{cm} 2$ dan kuat tekan karakteristik $129.59 \mathrm{~kg} / \mathrm{cm} 2$ dengan nilai modulus kehalusan agregat halu sebesar 2.170 dan Quarry Kampung Seberang memiliki nilai kuat tekan beton rata-rata $146.58 \mathrm{~kg} / \mathrm{cm} 2$ dan kuat tekan karakteristik $122.84 \mathrm{~kg} / \mathrm{cm} 2$ dengan nilai modulus kehalusan agregat halus sebesar 1.836 .

\section{Kesimpulan}

Berdasarkan hasil dan pembahasan yang ada, maka dapat ditarik kesimpulan sebagai berikut :

1. Agregat halus dari Quarry Tanjung Wagom, Quarry Kampung Seberang, Quarry Kampung Sungai dan agregat kasar dari Quarry Kayuni Secara umum dapat digunakan untuk bahan campuran beton karena memenuhi syarat karakteristik agregat beton tetapi yang paling baik agregat halus (pasir) yang paling baik adalah quarry Tanjung Wagom karena merupakan pasir yang paling baik untuk campuran beton dengan modulus kehalusan 2.93 dan masuk dalam zone 2 .

2. Kuat tekan karakteristik yang dihasilkan dari Quarry Kampung Seberang 122,84 kg/cm2 quarry Kampung sungai $129,59 \mathrm{~kg} / \mathrm{cm} 2$ dan quarry Kampung Tanjung Wagom $144,27 \mathrm{~kg} / \mathrm{cm} 2$ dari mutu beton yang direncanakan $250 \mathrm{~kg} / \mathrm{cm} 2$ atau turun $50,86 \%$, quarry 
Kampung Sungai 48,16 \% dan quarry Tanjung Wagom turun $42,29 \%$ atau kekuatan hanya di capai pada Quarry kmpung seberang 49,14\%, quarry Kampung Sungai $51,84 \%$ dan quarry Tanjung Wagom turun $57,71 \%$.

Saran dan rekomendasi penelitian sebagai berikut :

1. Perlu penelitian lebih lanjut dengan menggunakan deviasi standar yang baik dan yang dapat diterima sesuai Peraturan Beton Indonesia 1971 untuk mengetahui kuat tekan karakteristik optimal yang dapat dicapai dengan menggunakan agregat halus dan kasar dari quarry yang sama.

2. Penelitian dapat juga dilanjutkan dengan metode trialmix mengubah faktor air semen ( W/C ) yang lebih kecil dari W/C yang digunakan pada penelitian ini.

3. Perlu penelitian lebih lanjut dengan variasi (kombinasi) pasir dari pasir quarry Tanjung Wagom dengan Quarry Kampung Sungai kemudian variasi (kombinasi) dari ketiga quarry tersebut untuk mendapatkan pasir yang paling baik untuk campuran beton dan mendapatkan kuat tekan beton yang optimal.

\section{Ucapan Terima Kasih}

Ucapan terima kasih disampaikan kepada Jurusan Teknik Sipil Politeknik Negeri Fakfak atas dukungan prasana Laboratorium Uji Bahan pada saat pemerikaan agregat, pembuatan, serta pengujian kuat tekan benda uji.

\section{Daftar Pustaka}

[1] Mulyono, T. 2005. Teknologi Beton. Yogyakarta: Penerbit ANDI.

[2] Kabupaten Fakfak Dalam Angka 2012. Badan Pusat Statistik Kabupaten Fakfak.

[3] SNI 03-6861.1-2002. Spesifikasi Bahan Bangunan Bagian A (Bahan Bangunan Bukan Logam). Puslitbang Permukiman. 2002

[4] Dumyati, Ahmad. 2015 Analisis Penggunaan Pasir Pantai Sampur Sebagai Agregat Halus Terhadap Kuat Tekan Beton. Jurnal Frofil Vol. 3 No. 1 Juli - Desember 2015

[5] Attamimi, Aqilah. 2015. Perbandingan Kuat Tekan Beton Menggunakan Pasir laut dan Pasir Sungai terhadap Kuat Tekan Mutu Beton K-250. Laporan Tugas Akhir Program Studi Teknik Sipil Politeknik Negeri Fakfak. Fakfak

[6] SK SNI 03-1974-1990. Kuat Tekan Beton. Badan Standardisasi Nasional. 1990. 